\title{
EFEKTIFITAS PEMBELAJARAN BERBASIS KOGNITIF MORAL MELALUI MODEL VALUE CLARIFICATION TECHNIQUE (VCT) DITINJAU DARI HASIL BELAJAR PKn DENGAN MEMPERTIMBANGKAN MORAL JUDGEMENT
}

\author{
Yogi Prihandoko \\ priehandoko@gmail.com \\ Alumni Program Studi PGSD \\ FKIP - Universitas Kristen Satya Wacana \\ Wasitohadi \\ Program Studi PGSD \\ FKIP - Universitas Kristen Satya Wacana
}

\begin{abstract}
ABSTRAK
Tujuan penelitian ini adalah untuk mengetahui perbedaan tingkat efektivitas antara penerapan pembelajaran berbasis kognitif moral melalui model VCT dengan pembelajaran konvensional ceramah bervariasi terhadap hasil belajar PKn dengan mempertimbangkan moral judgement. Jenis penelitiannya adalah Experimen Research tipe Quasi Exsperimental Research serta menggunakan desain penelitian Nonequivalent Control Group Design. Subjek penelitian adalah siswa kelas 5 SDN Karangduren 01 sebagai kelompok eksperimen dan kelas 5 SDN Karangduren 02 sebagai kelompok kontrol. Teknik pengumpulan data yang digunakan adalah tes dan observasi. Sedangkan teknik analisis data menggunakan uji-t dengan SPSS 22.0. Hasil penelitian menunjukkan bahwa penerapan pembelajaran berbasis kognitif moral melalui model VCT efektif terhadap hasil belajar PKn dengan mempertimbangkan moral judgement siswa kelas 5 SD N Karangduren 01 Kecamatan Tengaran Kabupaten Semarang semester II tahun pelajaran 2014/2015. Simpulan tersebut didukung oleh hasil uji-t dengan hasil t hitung $>\mathrm{t}$ tabel $(2,085>2,00488)$, signifikansi $<0,05(0,042<0,05)$ serta skor hasil belajar PKn kelompok eksperimen lebih tinggi daripada kelompok kontrol $(76,2>68,5)$.
\end{abstract}

Kata kunci: Model Pembelajaran Value Clarification Technique, Hasil Belajar PKn, Moral Judgement.

\section{PENDAHULUAN}

Pendidikan Kewarganegaraan (selanjutnya ditulis $\mathrm{PKn}$ ) merupakan mata pelajaran yang termasuk dalam kelompok kewarganegaraan dan kepribadian. Menurut Badan Nasional Standar Pendidikan tahun 2007, maksud dan tujuan kelompok mata pelajaran kewarganegaraan dan kepribadian adalah untuk mencapai hasil belajar yang meliputi tiga aspek, yaitu pemahaman akan hak dan kewajiban diri sebagai warga negara, membentuk kepribadian, dan perilaku berkepribadian.

Mengacu pada maksud dan tujuan tersebut, dapat dikatakan bahwa PKn merupakan mata pelajaran penting dalam 
membentuk seorang individu yang memiliki kepribadian dan berperilaku baik, sesuai dengan nilai-nilai serta kaidah moralitas dalam kehidupan bermasyarakat, berbangsa dan bernegara. Oleh karena itu, pemahaman tentang nilai-nilai serta kaidah moralitas merupakan bekal utama bagi seorang anak untuk menjadi manusia yang berkarakter sesuai dengan jati diri bangsa. Pemahaman tentang nilai moral tersebut dapat diperoleh anak melalui proses pendidikan moral.

Sebagai upaya membelajarkan nilainilai moral, pendidik dalam hal ini adalah guru perlu mencari sebuah solusi yang tepat dalam pembelajaran PKn khususnya agar mengubah persepsi siswa sekaligus menjadikan PKn sebagai sebuah media untuk menanamkan nilai-nilai moral pada siswa. Salah satu kompetensi yang tepat dikembangkan dalam pembelajaran nilai-nilai moral dalam PKn dengan tetap mempertimbangkan tahap-tahap perkembangan kognitif adalah moral judgement. Moral judgement dimaknai sebagai kemampuan untuk membuat kesimpulan atau keputusan tentang sesuatu, baik yang berkaitan dengan berbagai dilema/konflik moral antar hal yang harus menjadi kenyataan maupun yang berhubungan dengan pihak lain. Dalam upaya mengembangkan kompetensi moral judgement diperlukan sebuah model pembelajaran yang cocok dalam mengembangkan dan membelajarkan nilai-nilai moral. Model pembelajaran Value Clarification Technique sebagai sebuah model pembelajaran yang berkonsentrasi pada penanaman nilai dianggap tepat dalam pengembangan moral judgement.

Mengingat pembelajaran moral dengan pendekatan kognitif yang masih jarang diterapkan oleh sebagian besar pendidik, ditambah dengan minimnya pengetahuan tentang model VCT menimbul- kan keraguan akan keefektifan pembelajaran berbasis kognitif moral melalui model VCT. Atas dasar keraguan tersebut peneliti bermaksud melakukan penelitian guna mengetahui keefektifan pembelajaran berbasis kognitif moral melalui model VCT dengan membandingkannya dengan pembelajaran konvensional ceramah bervariasi yang dimodifikasi sedemikian rupa hingga menyerupai model VCT. Namun, kegiatan modifikasi tersebut tidak dapat sepenuhnya/ sama persis karena ada sebuah ciri khas dari model pembelajaran yang tetap tidak dapat ditiru yang tidak menutup kemungkinan menjadi sebuah keunggulan maupun kelemahan.

Adapun rumusan masalah dalam penelitian ini adalah: apakah ada perbedaan tingkat efektivitas antara penerapan pembelajaran berbasis kognitif moral melalui model VCT dengan pembelajaran konvensional ceramah bervariasi terhadap hasil belajar PKn dengan mempertimbangkan moral judgement siswa kelas 5 SD N Karangduren 01 Kecamatan Tengaran Kabupaten Semarang semester II tahun pelajaran 2014/2015?

Manfaat yang dapat diharapkan dari penelitian ini dibagi menjadi dua yaitu manfaat teoritis dan praktis. Manfaat teoritis dari penelitian ini adalah untuk mendukung dan mengokohkan teori yang berkenaan dengan pembelajaran berbasis kognitif moral yang dikolaborasikan dengan model pembelajaran VCT dalam proses pembelajaran PKn khususnya pengembangan kemampuan moral judgement. Sedangkan manfaat praktisnya, bagi guru, penelitian ini diharapkan dapat menambah kompetensi dalam membelajarkan nilai-nilai moral dalam proses pembelajaran PKn pada siswa terutama dengan menggunakan pembelajaran berbasis kognitif moral yang dikolaborasikan 
dengan model pembelajaran VCT. Sedangkan bagi siswa, penelitian ini diharapkan dapat mengembangkan kemampuan moral judgement yang sangat penting dimiliki oleh siswa karena nantinya akan dipergunakan sebagai modal utama dalam menghadapi masalahmasalah moral yang dilematis.

\section{TINJAUAN PUSTAKA}

\section{Pendidikan Kewarganegaraan}

Pengertian PKn dalam Permendiknas No. 22 Tahun 2006 tentang standar isi tertulis bahwa PKn adalah mata pelajaran yang memfokuskan pada pembentukan warga negara yang memahami dan mampu melaksanakan hak-hak dan kewajibannya untuk menjadi warga negara Indonesia yang cerdas, terampil, dan berkarakter yang diamanatkan oleh Pancasila dan UUD 1945. Lebih lanjut Mawardi (2010:11) menjelaskan bahwa terdapat beberapa komponen penting dalam PKn yaitu:

a. PKn merupakan salah satu sub sistem pendidikan nasional.

b. Kajian PKn meliputi pemerintahan, konstitusi,lembaga-lembaga demokrasi, rule of law, HAM, hak dan kewajiban warga negara.

c. PKn merupakan alat pendidikan demokrasi. d. PKn sebagai wahana pendidikan politik warga negara.

Berdasarkan uraian di atas dapat dimaknai bahwa PKn merupakan sebuah mata pelajaran yang bermaksud membentuk warga negara yang baik, yakni warga negara yang mampu memahami, melaksanakan, serta menjiwai jati diri bangsa Indonesia dengan segala hak-hak dan kewajibannya sebagaimana diamanatkan dalam Pancasila dan UUD 1945.

Mengacu pada pengertian dan hakekat PKn, implementasi pembelajaran PKn pada pendidikan dasar lebih lanjut dimuat dalam Permendiknas nomor 22 tahun 2006 tentang standar isi untuk satuan pendidikan dasar dan menengah untuk kemudian diuraikan lebih lanjut dalam Standar Kompetensi dan Kompetensi Dasar. Standar Kompetensi adalah "ukuran kemampuan minimal yang mencakup pengetahuan, keterampilan dan sikap yang harus dicapai, diketahui, dan mahir dilakukan oleh siswa pada setiap tingkatan dari suatu materi yang diajarkan", sedangkan kompetensi dasar adalah "penjabaran standar kompetensi siswa yang cakupan materinya lebih sempit". Berikut adalah Standar Kompetensi (SK) dan Kompetensi Dasar (KD) PKn kelas 5 semester II:

Tabel 1 Standar Kompetensi dan Kompetensi Dasar PKn SD/MI Kelas 5 Semester II

\begin{tabular}{ll}
\hline \multicolumn{1}{c}{ Stándar Kompetensi } & \multicolumn{1}{c}{ Kompetensi Dasar } \\
\hline $\begin{array}{l}\text { 3.Memahami kebebasan } \\
\text { berorganisasi. }\end{array}$ & $\begin{array}{l}\text { 3.1 Mendeskripsikan pengertian organisasi. } \\
\text { 3.2 Menyebutkan contoh organisasi di lingkungan sekolah dan } \\
\text { masyarakat. } \\
\text { 3.3 Menampilkan peran serta dalam memilih organisasi di sekolah. }\end{array}$ \\
\hline $\begin{array}{l}\text { 4.Menghargai keputusan } \\
\text { bersama. }\end{array}$ & $\begin{array}{l}\text { 4.1 Mengenal bentuk-bentuk keputusan bersama. } \\
\text { 4.2 Mematuhi keputusan bersama. }\end{array}$ \\
\hline
\end{tabular}

Sumber: Permendiknas No. 22 tahun 2006 tentang Standar Isi Untuk Satuan Pendidikan Dasar dan Menengah 


\section{Moral dan Moral Judgement}

Moral dalam arti yang luas mencakup bagaimana hubungan dengan Tuhan, hubungan sesama manusia dan hubungan dengan alam semesta. Menurut Syahrin (2005:45) orang yang memiliki moral yang baik adalah yang mampu menyeimbangkan hubungan dengan Tuhan, hubungan sesama manusia dan hubungan dengan alam semesta pada setiap tempat dan setiap waktu. Menurut Sastraprateja (dalam Adisusilo, 2012:53) moralitas atau juga disebut sebagai moral diartikan sebagai "perilaku manusia dan norma-norma yang dipegang masyarakat yang mendasarinya". Istilah moral berkenaan dengan kesusilaan. Seorang individu dapat dikatakan baik secara moral apabila bertingkah laku sesuai dengan kaidah-kaidah moral dan aturan-aturan tentang bagaimana seharusnya seseorang hidup di dalam masyarakat dan begitu pula sebaliknya.

Menurut Sarbaini (2012:19) konsep pertimbangan moral (moral judgement) adalah sebuah manifestasi dalam membuat keputusan yang berkenaan dengan dilema/ konflik moral. Pertimbangan moral dapat dijadikan prediktor terhadap dilakukannya tindakan tertentu pada situasi yang melibatkan moral. Hal ini sejalan dengan apa yang dikemukakan oleh Kohlberg (dalam Adisusilo, 2012:2) bahwa "pertimbangan moral merupakan faktor yang amat menentukan perilaku moral".

Sebagai makhluk hidup, manusia terus berkembang, demikian pula pemikiran, tingkah laku, sikap dan moralnya. Kohlberg (dalam Sarbaini, 2012:21-25) mengemukakan tahap-tahap perkembangan penalaran moral sebagai berikut. Pertama, tingkat prakonvensional. Pada tahap ini anak tanggap terhadap aturan-aturan budaya dan ungkapan-ungkapan budaya mengenai baik dan buruk, atau benar dan salah. Akan tetapi hal ini ditafsirkan dari segi menghindari hukuman atau untuk mendapatkan hadiah. Tingkat ini biasanya terdapat pada usia 4 sampai 10 tahun. Terdapat dua tahap pada tingkat ini yaitu orientasi hukuman dan kepatuhan dan orientasi relativis-instrumental.

Kedua, tingkat konvensional. Individu pada tingkat konvensional menemukan pemikiran-pemikiran moral pada masyarakat. Pada tingkat ini seseorang menyadari dirinya sebagai seorang individu di tengah-tengah keluarga, masyarakat dan bangsanya. Keluarga, masyarakat, dan bangsa dinilai memiliki kebenarannya sendiri, karena jika menyimpang dari kelompok ini akan terisolasi. Oleh karena itu, kecenderungan individu pada tahap ini adalah menyesuaikan diri dengan aturan-aturan masyarakat dan mengidentifikasikan dirinya terhadap kelompok sosialnya. Tingkat ini berkisar usia 10 sampai 13 tahun. Tingkat ini mempunyai dua tahap yakni orientasi kesepakatan antara pribadi/orientasi "anak manis" dan orientasi hukum dan ketertiban.

Ketiga, tingkat pasca-konvensional. Tingkat ini disebut juga moralitas yang berprinsip (principled morality). Pada tingkat ini terdapat usaha yang jelas untuk merumuskan nilai-nilai dan prinsip moral yang memiliki keabsahan dan dapat diterapkan terlepas dari otoritas kelompok atau orang yang berpegang pada prinsip-prinsip itu dan terlepas pula dari identifikasi individu sendiri dengan kelompok tersebut. Tahap ini sudah dimulai dari remaja awal sampai seterusnya. Ada dua tahap pada tingkat ini yaitu orientasi kontrak sosial legalistis dan orientasi prinsip etika universal.

\section{Model Pembelajaran Value Clarification Technique (VCT)}

Hall (dalam Adisusilo, 2012:145) mengartikan teknik klarifikasi nilai (VCT) 
sebagai " a methodology or process by which we help a person to discover values through behavior, feelings, ideas, and through important choices he has made and is continually, in fact, acting uppon in and through his life." Dengan demikian, teknik klarifikasi nilai adalah suatu metodologi atau proses dimana kita membantu seseorang untuk menemukan nilai-nilai melalui perilaku, perasaan, ide, dan pilihan-pilihan penting yang telah ia lakukan dan secara terus-menerus bertindak berdasarkan nilainilai itu di dalam dan melalui hidupnya".

Menurut Sanjaya (2008:88), VCT merupakan "teknik pengajaran untuk membantu siswa dalam mencari dan menentukan suatu nilai yang dianggap baik dalam menghadapi suatu persoalan melalui proses menganalisis nilai yang sudah ada dan tertanam dalam diri siswa”. Berdasarkan pendapat tersebut, dapat disimpulkan bahwa VCT merupakan pembelajaran nilai yang mampu mengarahkan peserta didik agar mempunyai keterampilan atau kemampuan menentukan nilai-nilai hidup yang tepat sesuai dengan tujuan hidupnya.

Menurut John Jarolimek (dalam Wina Sanjaya, 2006:284-285) pembelajaran VCT dilaksanakan dalam tujuh tahap yang dibagi dalam tiga tingkat. Adapun setiap tahapan adalah sebagai berikut:

1. Kebebasan memilih. Pada tingkat kebebasan memilih ada tiga tahap yaitu:

a. Memilih secara bebas, artinya kesempatan untuk menentukan pilihan yang menurutnya baik.

b. Memilih dari beberapa alternatif, artinya menentukan pilihannya dari beberapa alternatif pilihan secara bebas.

c. Memilih setelah melakukan analisis pertimbangan konsekuensi yang akan timbul sebagai akibat atas pilihannya itu.
2. Menghargai. Pada tingkat menghargai ada dua tahap yaitu:

a. Adanya perasaan senang dan bangga dengan nilai yang menjadi pilihannya, sehingga nilai tersebut akan menjadi integral pada dirinya.

b. Menegaskan nilai yang sudah menjadi bagian integral dalam dirinya di depan umum.

3. Berbuat. Pada tingkat berbuat ada dua tahap yaitu:

a. Adanya kemauan dan kemampuan untuk mencoba melaksanakannya.

b. Mau mengulangi perilaku sesuai dengan nilai pilihannya.

Lebih lanjut Hall (dalam Adisusilo, 2012: 160) menjelaskan langkah-langkah pembelajaran VCT yang ditampilkan dalam bentuk bagan (Gambar 1).

Setiap model pembelajaran pasti memiliki keunggulan dan kelemahan, demikian pula VCT juga memiliki keunggulan dan kelemahan. Adisusilo (2012:152) mengungkapkan bahwa VCT memiliki kelebihan diantaranya:

a. Membantu siswa untuk berproses menyadari dan mengidentifikasi nilai-nilai mereka sendiri serta nilai-nilai orang lain.

b. Membantu siswa supaya mereka mampu berkomunikasi secara terbuka dan jujur dengan orang lain, berhubungan dengan nilai-nilainya sendiri.

c. Membantu siswa supaya mampu menggunakan secara bersama-sama kemampuan berpikir rasional dan kesadaran emosional, untuk memahami perasaan, nilai-nilai, sikap dan pola tingkah laku mereka sendiri dan akhirnya didorong untuk menghayatinya.

Beberapa kelemahan model VCT menurut Djahiri (dalam Taniredja, 2011:91) adalah sebagai berikut:

a. Apabila guru/dosen tidak memiliki kemampuan melibatkan peserta didik dengan keterbukaan, saling pengertian 
dan penuh kehangatan maka siswa akan memunculkan sikap semua atau imitasi/ palsu. Siswa akan bersikap menjadi sangat baik, ideal, patuh dan penurut, namun hanya bertujuan untuk menyenangkan guru atau memperoleh nilai yang baik.

b. Sistem nilai yang dimiliki dan tertanam guru/dosen, peserta didik dan masyarakat yang kurang atau tidak baku dapat mengganggu tercapainya target nilai baku yang ingin dicapai/nilai etik.

c. Sangat dipengaruhi oleh kemampuan guru/dosen dalam mengajar terutama memerlukan kemampuan/keterampilan bertanya tingkat tinggi yang mampu mengungkap dan menggali nilai yang ada dalam diri peserta didik.

\section{Pembelajaran Konvensional Ceramah}

\section{Bervariasi}

Pembelajaran konvensional selalu diidentikkan dengan ceramah. Hal tersebut sesuai dengan pendapat Djamarah dalam Jurnal Ilmiah Pendidikan ke-SD-an "Scholaria" (2011:216-220) yang menyatakan bahwa "pembelajaran konvensional ditandai dengan ceramah, pemberian tugas dan latihan". Ceramah adalah pembelajaran yang sering dikenal sebagai pembelajaran pasif, satu arah, dan teacher centered. Hal tersebut membuat sebagian orang terkadang memandang sebelah mata terhadap pembelajaran konvensional. Padahal, pembelajaran ceramah akan tetap diperlukan untuk menerangkan beberapa konsep-konsep baru atau pembelajaran yang bersifat klasikal. Berdasarkan hal tersebut, maka diperlukan optimalisasi pembelajaran konvensional sehingga seiring dengan perkembangan jaman pembelajaran konvensional tidak hanya stagnan namun dinamis.

Sebagai salah satu upaya dalam optimalisasi tersebut, ceramah bervariasi adalah perpaduan yang tepat dalam mengem- bangkan pembelajaran konvensional. Ceramah bervariasi yang dimaksud adalah ceramah yang divariasi dengan diskusi kelompok. Dengan divariasi dengan diskusi, pembelajaran akan membuat siswa lebih aktif dan kreatif dalam berkomunikasi dan mengungkapkan pendapat. Ceramah bervariasi dilaksanakan melalui langkah-langkah yang menjadi pedoman dalam implementasinya. Sudjana (2010:124) menjelaskan langkah-langkah teknik ceramah bervariasi sebagai berikut:

1. Pendidik, mungkin pula dengan mengikutsertakan peserta didik, menyusun topik yang akan dipelajari berdasarkan kebutuhan belajar. Kemudian pendidik menyusun pokok-pokok informasi yang akan disampaikan kepada para peserta didik.

2. Pendidik memilih, menetapkan, dan menyiapkan alat-alat bantu pandang dengar yang cocok dengan pokok-pokok informasi, sebagai alat bantu dalam penyampaian informasi itu dan menetap-kan sumber-sumber lainnya yang akan dipelajari oleh para peserta didik.

3. Pendidik menetapkan teknik-teknik kegiatan belajar partisipatif lainnya yang akan digunakan setelah pokok-pokok informasi itu disampaikan.

4. Pendidik membantu peserta didik untuk melakukan kegiatan belajar dengan tahapan sebagai berikut:

a. Pendidik menjelaskan pokok-pokok informasi

b. Pendidik menunjukkan sumbersumber lain misalnya buku-buku, laporan kegiatan dan jurnal yang dapat digunakan oleh para peserta didik untuk memperluas pemahaman tentang informasi yang disampaikan.

c. Para peserta didik, dalam sub-sub kelompok atau kelompok besar, mempelajari sumber-sumber lain untuk memperdalam pemahaman tentang informasi yang disampaikan oleh pendidik. 
d. Pendidik memberi tugas kepada para peserta didik untuk menggunakan teknik-teknik lain dalam membahas pokok-pokok informasi ini dengan teknik lain itu para peserta didik dapat menyusun tanggapan, pertanyaan, sanggahan dan lain sebagainya yang dapat diajukan kepada pendidik dan semua peserta didik.

e. Pendidik bersama para peserta didik memberi jawaban terhadap pertanyaan dan memberi penjelasan tentang hasil kegiatan dari kelompok atau dari seluruh peserta didik.

5. Pendidik bersama peserta didik melakukan evaluasi terhadap proses dan hasil kegiatan belajar dengan penggunaan teknik ini.
Suatu pembelajaran pasti memiliki kekurangan dan kelebihan, begitu juga dengan ceramah bervariasi. Menurut Sudjana (2010:125) keunggulan teknik ceramah bervariasi diantaranya:

1. Waktu yang disediakan dapat digunakan secara efektif dan efisien.

2. Dapat digunakan pada kelompok peserta didik yang besar jumlahnya.

3. Dapat digunakan untuk merangsang peserta didik guna memperluas atau memperdalam informasi melalui kegiatan belajar dengan teknik-teknik lain.

4. Lebih efektif apabila digunakan bagi para peserta didik yang telah dewasa.

5. Kegiatan belajar dapat menampung pendapat, tanggapan, dan pertanyaan dalam suasana yang mungkin menggembirakan.

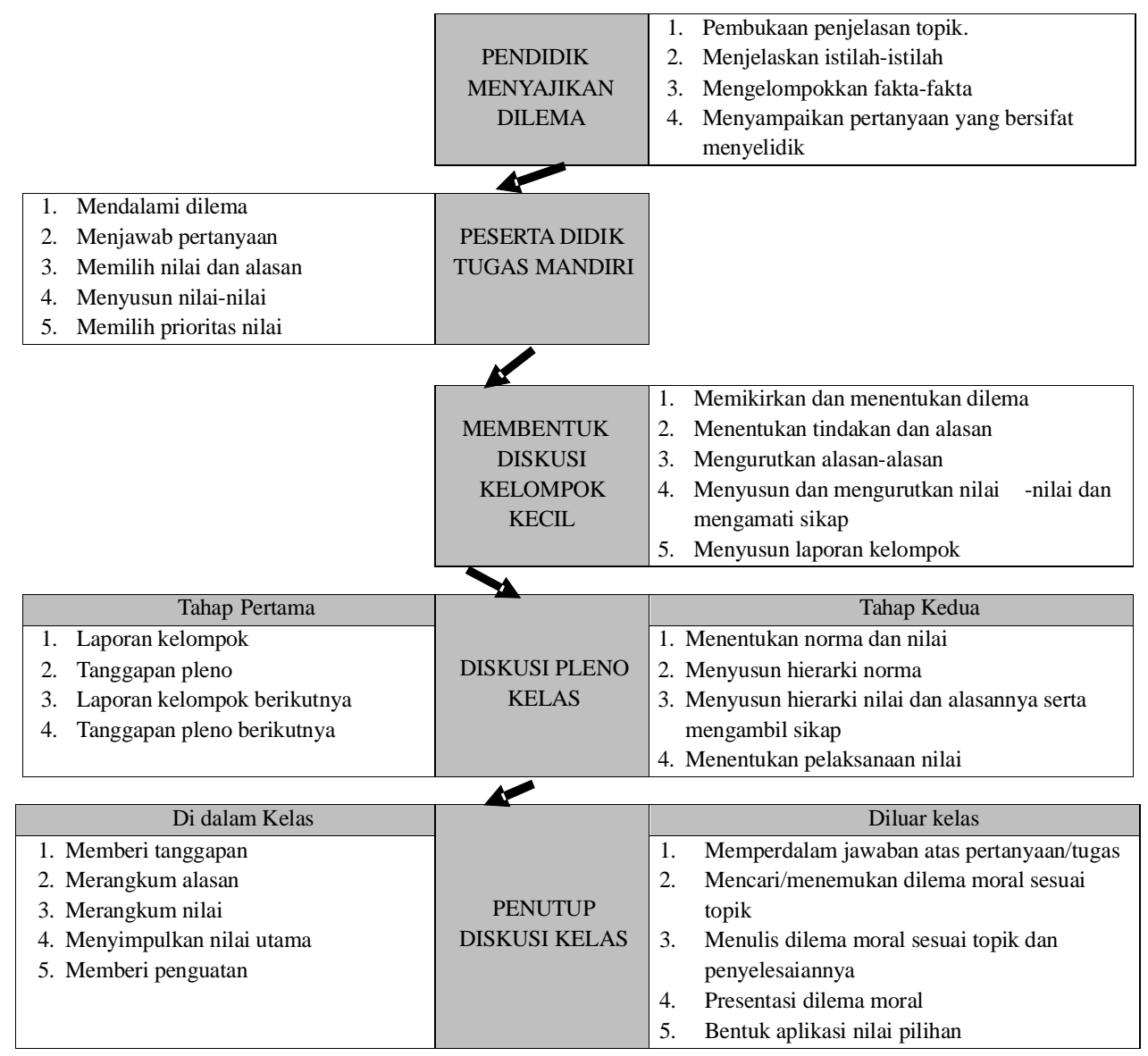

Sumber: Sutarjo Adisusilo 2012:160

Gambar 1 Langkah-Langkah Pembelajaran VCT 
Sedangkan kelemahannya yakni:

1. Peserta didik terhalang untuk merespon secara langsung pada saat pokok-pokok informasi yang disampaikan.

2. Waktu yang digunakan mungkin tidak cukup terutama apabila peserta didik sangat aktif dalam kegiatan melalui teknik-teknik lainnya.

3. Pendidik harus menguasai pokok-pokok informasi dan sumber-sumber lain, terlatih dalam memotivasi dan menyampaikan informasi.

4. Relatif sulit digunakan bagi peserta didik yang belum dewasa, tuna aksara, dan berkelainan.

5. Tidak semua jawaban dan penjelasan dari pertanyaan dan tanggapan peserta didik dapat memuaskan setiap orang.

\section{Hasil Belajar}

Hasil belajar siswa dipengaruhi oleh banyak hal, salah satunya adalah efektifitas perlakuan pembelajaran. Semakin efektif perlakuan pembelajaran hasil belajar siswa semakin baik/ tinggi. Menurut Nawawi (dalam Ahmad Susanto 2013:5) "hasil belajar dapat diartikan sebagai tingkat keberhasilan siswa dalam mempelajari materi pelajaran di sekolah dengan dinyatakan dalam skor yang diperoleh dari hasil tes mengenai sejumlah materi pelajaran tertentu”. Selanjutnya Ruminiati (2007:8) menyatakan bahwa "hasil belajar merupakan hasil interaksi stimulus dari luar dengan schemata siswa". Sedangkan Sardiman (2007: 2) menyatakan bahwa "hasil belajar merupakan hasil perubahan tingkah laku dalam dirinya, baik perubahan yang bersifat pengetahuan, keterampilan, sikap, dan bersifat relatif permanen".

Berdasarkan pendapat di atas, dapat disimpulkan bahwa hasil belajar merupakan hasil proses belajar individu akibat interaksi pengetahuan yang dimiliki dengan stimulus dari luar dirinya berupa pengetahuan, keterampilan, sikap, dan bersifat permanen. Menurut Ahmad Susanto (2013:6-10) hasil belajar meliputi tiga aspek, yaitu: (a) pemahaman konsep (aspek kognitif). Melalui produk dapat diselidiki apakah dan sampai berapa jauh suatu tujuan instruksional telah tercapai, semua tujuan itu merupakan hasil belajar siswa yang erat hubungannya dengan tujuan instruksional (pembelajaran);(b) keterampilan proses. Keterampilan proses merupakan keseluruhan keterampilan ilmiah yang terarah (baik kognitif maupun psikomotorik) yang dapat digunakan untuk menemukan suatu konsep atau prinsip atau teori, untuk mengembangkan konsep yang telah ada sebelumnya, atau untuk melakukan penyangkalan terhadap suatu penemuan (falsifikasi); dan (c) sikap. Hasil belajar berupa sikap tidak hanya merupakan aspek mental semata, melainkan mencakup pula aspek respons fisik. Harus ada kekompakan antara mental dan fisik secara serempak.

Hasil belajar yang dicapai siswa dapat dipengaruhi oleh beberapa faktor yang diantaranya dikemukakan oleh Carol (dalam Sudjana, 2004:39) bahwa hasil belajar yang dicapai siswa dipengaruhi oleh lima faktor, yakni (a) bakat pelajar, (b) waktu yang tersedia untuk belajar, (c) waktu yang diperlukan siswa untuk menjelaskan pelajaran, (d) kualitas pengajaran, dan (e) kemampuan individu. Empat faktor yang disebut di atas (a, b, c, e) berkenaan dengan kemampuan individu dan faktor (d) adalah faktor di luar individu (lingkungan).

Ada beberapa hasil penelitian tentang penerapan model pembelajaran VCT, salah satunya adalah penelitian quasi eksperimen dilakukan oleh Ni Pt. Yoni Rahayudhi, A. A. Gd.Agung, dan I Dw. Kade Tastra. Judul penelitian ini adalah "Pengaruh Model Pembelajaran VCT Berbantuan Media 
Microsoftpowerpoint terhadap Prestasi Belajar PKn Siswa Kelas V SD gugus II Kecamatan Tegallalang" yang dipublikasikan dalam jurnal online Universitas Pendidikan Ganesha Singaraja. Hasil penelitian ini berdasarkan uji hipotesis yang telah dilakukan dengan menggunakan uji-t ditemukan bahwa terdapat perbedaan yang signifikan model pembelajaran VCT berbantuan media microsoft powerpoint terhadap prestasi belajar PKn siswa diketahui bahwa thitung $>\mathrm{t}$ tabel $(9,23>2,00$ dengan taraf signifikansi $5 \%$.

Dewi Anggarini, I Nym. Murda, dan I Wyn. Sudiana (2012) juga melakukan penelitian quasi eksperimen dengan judul "Pengaruh Model Pembelajaran Value Clarification Technique Berbantuan Media Gambar terhadap Nilai Karakter Siswa Kelas V SD Gugus VI Tajun Kecamatan Kubutambahan Tahun Ajaran 2012/2013” yang dipublikasikan dalam jurnal online Universitas Pendidikan Ganesha Singaraja. Dalam penelitian ini disimpulkan bahwa terdapat perbedaan yang signifikan pada nilai karakter siswa kelas V semester II antara kelompok siswa yang dibelajarkan dengan model VCT berbantuan media gambar dan kelompok siswa yang dibelajarkan dengan model pembelajaran konvensional. Kesimpuan didukung dengan hasil perhitungan uji-t diperoleh $\mathrm{t}$ hit $>\mathrm{t}$ tab $=5,47$ dan $\mathrm{t}$ tab $=2,035$ serta rata-rata skor hasil belajar siswa kelas eksperimen yang lebih besar dari kelas kontrol $(76,35>65,67)$.

\section{Hipotesis Penelitian}

Berdasarkan uraian kajian teori dan kajian penelitian yang relevan, dirumuskan hipotesis alternatif: terdapat perbedaan tingkat efektivitas antara pembelajaran berbasis kognitif moral melalui model VCT dengan pembelajaran konvensional ceramah bervariasi ditinjau dari hasil belajar PKn dengan mempertimbangkan moral judgement siswa kelas 5 SD N Karangduren 01 Kecamatan Tengaran Kabupaten Semarang Semester II Tahun Pelajaran 2014/2015. Sedangkan hipotesis nol dari penelitian adalah: tidak terdapat perbedaan tingkat efektivitas antara pembelajaran berbasis kognitif moral melalui model VCT dengan pembelajaran konvensional ceramah bervariasi terhadap hasil belajar PKn dengan mempertimbangkan moral judgement siswa kelas 5 SD N Karangduren 01 Kecamatan Tengaran Kabupaten Semarang Semester II Tahun Pelajaran 2014/2015.

\section{METODE PENELITIAN}

Jenis penelitian yang digunakan adalah penelitian eksperimen tipe Quasi Eksperimental Research. Desain eksperimen yang digunakan adalah Nonequivalent Control Group Design dimana kedua kelompok, baik kelompok eksperimen maupun kelompok kontrol, tidak dipilih secara random. Setelah diketahui kondisi kedua kelompok tersebut homogen atau seimbang, $\left(\mathrm{O}_{1}\right.$ tidak berbeda dengan $\left.\mathrm{O}_{3}\right)$ maka kelompok eksperimen diberi perlakuan (treatment) dengan menggunakan pembelajaran berbasis kognitif moral melalui model VCT dan kelompok kontrol diterapkan pembelajaran konvensional ceramah bervariasi. $\mathrm{O}_{2}$ adalah nilai post-test kelompok eksperimen setelah dilakukan penerapan pembelajaran berbasis kognitif moral melalui model VCT. $\mathrm{O}_{4}$ adalah nilai post-test kelompok kontrol yang diajar dengan menggunakan pembelajaran konvensional oleh guru kelas. Pengaruh treatment adalah bila rata-rata nilai $\mathrm{O}_{2}$ lebih besar dari $\mathrm{O}_{4}$ dan perbedaannya signifikan (Sugiyono, 2010:116). 
Tabel 2 Desain Eksperimen Pretestposttest Control Group Design

\begin{tabular}{ccc}
\hline $\mathrm{O}_{1}$ & $\mathrm{X}$ & $\mathrm{O}_{2}$ \\
\hline $\mathrm{O}_{3}$ & - & $\mathrm{O}_{4}$ \\
\hline
\end{tabular}

Variabel independen atau variabel bebas dalam penelitian ini adalah pembelajaran berbasis kognitif moral melalui model VCT. Sedangkan yang menjadi variabel dependen adalah hasil belajar PKn dengan mempertimbangkan moral judgement. Penelitian ini dilaksanakan pada bulan Februari sampai dengan bulan Maret tahun 2015. Subjek penelitiannya adalah siswa kelas 5 SD Negeri Karangduren 01 dan 02 pada semester II tahun ajaran 2014/2015 Kecamatan Tengaran, Kabupaten Semarang. Siswa kelas 5 SD Negeri Karangduren 01 sebagai kelompok eksperimen berjumlah 35 (tiga puluh lima) siswa dan siswa kelas 5 SD Negeri Karangduren 02 sebagai kelompok kontrol berjumlah 21 (dua puluh satu) siswa, sehingga jumlah keseluruhan dari unit penelitian adalah 56 (lima puluh enam) siswa.

Teknik pengumpulan data yang digunakan adalah tes dan observasi. Tes digunakan untuk mengumpulkan data hasil belajar kelompok eksperimen dan kelompok kontrol guna mengetahui perbedaan tingkat efektivitas penerapan pembelajaran berbasis kognitif moral melalui model VCT dan pembelajaran konvensional ceramah bervariasi. Sedangkan observasi digunakan untuk mendapatkan data tentang proses pembelajaran di dalam kelas. Instrumen pengumpulan data yang digunakan adalah butir soal tes dan lembar observasi. Butirbutir soal tes disusun berdasarkan pada Kompetensi Dasar PKn SD/MI kelas 5 poin 4.2 "Mematuhi keputusan bersama". Butirbutir soal tersebut terdiri atas 10 butir soal pilihan ganda dan 20 butir soal uraian. Sedangkan lembar observasi berupa penilaian checklist yang disesuaikan dengan sintaks penerapan pembelajaran berbasis kognitif moral melalui model VCT dan pembelajaran konvensional ceramah bervariasi.

Teknik analisis data yang digunakan meliputi uji instrumen (uji validitas dan reliabilitas), uji normalitas, uji homogenitas dan uji hipotesis yang menggunakan uji-t yang dilaksanakan menggunakan bantuan Software Statistical Product and Service Solution (selanjutnya ditulis SPSS) versi 22. Valid berarti instrumen tersebut dapat digunakan untuk mengukur apa yang seharusnya diukur. Sedangkan instrumen yang reliable adalah instrumen yang bila digunakan beberapa kali untuk mengukur objek yang sama, akan menghasilkan data yang sama.

Uji normalitas dilakukan untuk mengetahui apakah data hasil belajar yang berasal dari kedua kelas sampel berdistribusi normal atau tidak. Uji normalitas dilakukan dengan metode Kolmogorov Smirnov $Z$. Sedangkan Uji homogenitas bertujuan untuk menentukan apakah varian kedua kelompok homogen atau tidak. Homogenitas dilakukan untuk mengetahui apakah data dari masingmasing kelompok sampel mempunyai varians yang sama atau berbeda.

Uji hipotesis dilakukan untuk mengetahui apakah terdapat perbedaan tingkat efektivitas antara kelompok kontrol dan kelompok eksperimen yang signifikan setelah dilakukan tindakan berupa penggunaan pembelajaran berbasis kognitif moral melalui model VCT pada kelompok eksperimen. Jika data yang diperoleh berdistribusi normal dan homogen, maka pengujian menggunakan uji statistik parametrik, yaitu menggunakan uji-t atau T-test Independent. Menurut Priyatno (2010:99) 
menganalisis hasil output pada Independent Sample Test dilakukan menggunakan Equal Variance Assumed (diasumsikan varian sama) dan Equal Variance Not Assumed (diasumsikan varian berbeda). Jika signifikansi > 0,05 maka memiliki varian yang sama. Jika signifikansi $<0,05$ maka memiliki varian yang berbeda. Selanjutnya adalah dengan melihat tabel Independent Sample Test pada T-test for Equality of Means pada sig (2-tailed), jika signifikansi $>0,05$ maka tidak ada perbedaan. Jika signifikansi $<0,05$ maka terdapat perbedaan.

\section{HASIL PENELITIANDANPEMBAHASAN}

Data hasil penelitian diperoleh dari skor post-test kelas eksperimen dan kelas kontrol. Untuk mempermudah dalam membaca data skor hasil belajar, maka data mentah skor hasil belajar kelas eksperimen dan kelas kontrol akan disajikan dalam diagram garis sebagai berikut:

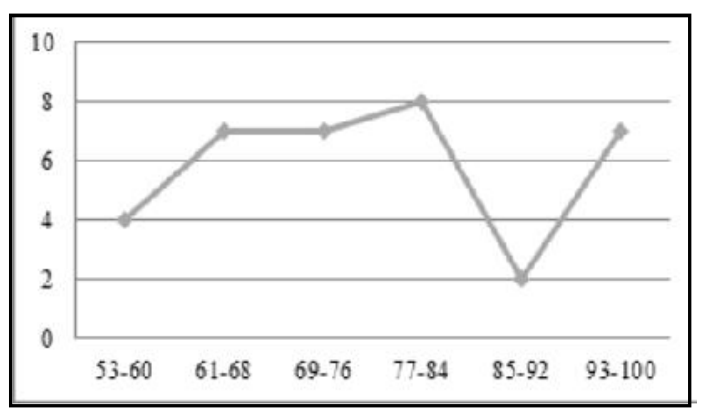

Gambar 2 Diagram Garis Skor Hasil Belajar PKn Kelas Eksperimen

Berdasarkan Gambar 2 dapat diketahui skor hasil belajar PKn kelas eksperimen siswa kelas 5 SD N Karangduren 01. Siswa yang mendapat skor 53 sampai 60 terdiri atas 4 siswa. Siswa yang mendapat skor antara 61 sampai 68 terdapat 7 siswa, begitu juga siswa yang mendapat nilai 69 sampai 76 juga sama yakni 7 siswa. Selanjutnya, siswa yang mendapat skor antara 77 sampai dengan 84 merupakan frekuensi terbesar yakni terdiri atas 8 siswa. Kemudian siswa yang mendapat skor 85 sampai 92 terdapat 2 siswa dan siswa yang menduduki interval kelas nilai tertinggi antara 93 sampai dengan 100 adalah 7 orang siswa.

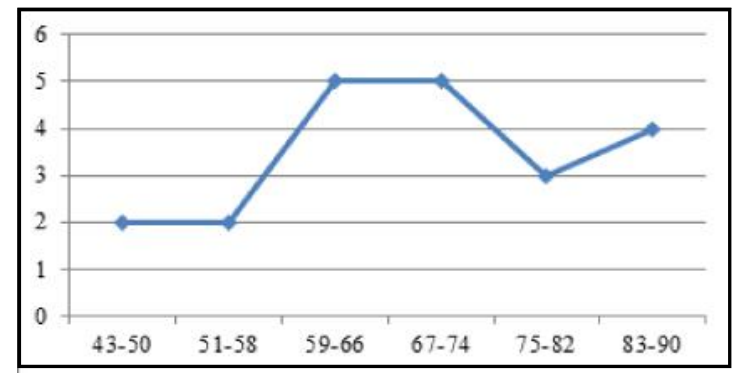

Gambar 3 Diagram Garis Skor Hasil Belajar PKn Kelas Kontrol

Berdasarkan Gambar 3 dapat diketahui skor hasil belajar PKn kelas kontrol siswa kelas 5 SD N Karangduren 02. Siswa yang mendapat skor 43 sampai 50 merupakan jumlah yang paling sedikit yakni 2 siswa, begitu juga siswa yang mendapat nilai antara 51 sampai 58 juga memiliki jumlah yang sama yakni 2 siswa. Selanjutnya siswa yang mendapat skor antara 59 sampai dengan 66 juga memiliki jumlah yang sama dengan siswa yang mendapat skor 67 sampai 74 yakni 5 siswa. Kemudian siswa yang mendapat skor 75 sampai 82 terdapat 3 siswa dan siswa yang menduduki interval nilai tertinggi 83 sampai dengan 90 adalah 4 orang siswa.

Setelah disajikan dengan menggunakan diagram batang, data diolah menggunakan analisis deskriptif sebagai berikut:

Tabel 3 Analisis Deskriptif

\begin{tabular}{lccccc}
\hline & N & Minimum & Maximum & Mean & Std. Deviation \\
\hline kelas_eksperimen & 35 & 53 & 98 & 76,20 & 13,222 \\
kelas_kontrol & 21 & 43 & 89 & 68,57 & 13,318 \\
ValidN(listwise) & 21 & & & & \\
\hline
\end{tabular}

Berdasarkan Tabel 3 dapat dilihat skor hasil belajar PKn kelas eksperimen dan kelas kontrol. Untuk kelas eksperimen, yakni kelas 5 SD N Karangduren 01 dengan jumlah data (N) 35 memiliki nilai minimum 53 dan nilai maksimum 98. Nilai rata-rata kelas eksperimen adalah 76,20 serta standar deviasi 13,222. Sedangkan untuk kelas 
kontrol (SD N Karangduren 02) dengan jumlah data (N) 21 memiliki nilai minimum 43 dan nilai maksimum 89. Nilai rata-rata kelas kontrol adalah 68,57 serta standar deviasi 13,318.

Analisis data selanjutnya adalah uji normalitas, berdasarkan hasil uji yang dilakukan dengan software SPSS dengan menggunakan analisis Kolmogorov-Smirnov didapatkan hasil signifikansi skor hasil belajar kelas eksperimen dan kelas kontrol sebesar 0,200 sehingga dapat disimpulkan bahwa data berdistribusi normal karena lebih besar dari 0,05 . Setelah data dinyatakan berdistribusi normal, analisis data selanjutnya adalah uji homogenitas. Berdasarkan hasil output uji homogenitas diperoleh signifikansi 0,869 yang artinya data tersebut dapat dinyatakan homogen karena lebih besar dari 0,05.

Analisis data terakhir sebagai dasar pengambilan keputusan adalah uji-t yang menggunakan Independent Sample T-Test dengan hasil output sebagai berikut: yakni 0,042. Selanjutnya, pada kolom mean different nampak bahwa perbedaan rata-rata sebesar 7,629 dan perbedaan berkisar antara 0,292 sampai 14,965 sebagaimana dapat dilihat pada kolom lower dan upper.

Berdasarkan hasil uji independent sample t-test menunjukkan bahwa hasil $\mathrm{t}$ hitung lebih besar dari t tabel dan signifikansi yang lebih kecil dari 0,05. Sebagaimana diketahui bahwa t tabel adalah 2,00488 sedangkan t hitung adalah 2,085 serta signifikansi dari hasil uji $\mathrm{t}$ independent sample $t$ test adalah 0,042 maka dapat disimpulkan bawa thitung $>$ dari t tabel atau 2,085>2,00488 dan signifikansi lebih kecil dari 0,05 atau 0,042<0,05. Dari kesimpulan tersebut, dapat diputuskan bahwa Ho ditolak sehingga $\mathrm{Ha}$ diterima. Hal ini berarti terdapat perbedaan efektivitas antara pembelajaran berbasis kognitif moral melalui model VCT dengan pembelajaran konvensional ceramah bervariasi terhadap hasil belajar PKn dengan mempertimbangkan moral judgement siswa kelas 5 SD

Tabel 4 Hasil Uji Independent Sample T-Test

\begin{tabular}{|c|c|c|c|c|c|c|c|c|c|c|}
\hline & & \multicolumn{2}{|c|}{$\begin{array}{l}\text { Equality of } \\
\text { Variances }\end{array}$} & \multicolumn{7}{|c|}{ t-test for Equality of Means } \\
\hline & & \multirow[t]{2}{*}{$\mathrm{F}$} & \multirow[t]{2}{*}{ Sig. } & \multirow[t]{2}{*}{$\mathrm{t}$} & \multirow[t]{2}{*}{$d f$} & \multirow[t]{2}{*}{$\begin{array}{l}\text { Sig. (2- } \\
\text { tailed) }\end{array}$} & \multirow[t]{2}{*}{$\begin{array}{c}\text { Mean } \\
\text { Difference }\end{array}$} & \multirow[t]{2}{*}{$\begin{array}{l}\text { Std. Error } \\
\text { Difference }\end{array}$} & \multicolumn{2}{|c|}{$\begin{array}{l}\text { 95\% Confidence } \\
\text { Interval of the } \\
\text { Difference }\end{array}$} \\
\hline & & & & & & & & & Lower & Upper \\
\hline \multirow[t]{2}{*}{ post_test } & $\begin{array}{l}\text { Equal variances } \\
\text { assumed }\end{array}$ & ,010 & 920 & 2,085 & 54 & ,042 & 7,629 & 3,659 & ,292 & 14,965 \\
\hline & $\begin{array}{l}\text { Equal variances } \\
\text { not assumed }\end{array}$ & & & 2,081 & 42,008 & ,044 & 7,629 & 3,666 & ,230 & 15,027 \\
\hline
\end{tabular}

Berdasarkan Tabel 4 dapat dilihat pada baris equal variances assumed karena varian data sama (homogen), ini dapat dilihat dari kolom sig. yang menunjukkan angka 0,920 yang artinya lebih besar dari 0,05. Pada kolom t menunjukkan bahwa hasil $t$ hitung adalah 2,085 serta signifikasi yang dapat dilihat pada kolom sig. (2-tailed)
Karangduren 01 semester II tahun pelajaran 2014/2015.

Hasil penelitian yang menunjukkan ditolaknya Ho sehingga berimplikasi diterimanya Ha dipengaruhi oleh beberapa faktor yang diantaranya telah disampaikan oleh Sanjaya (2008:88) bahwa VCT merupakan "teknik pengajaran untuk 
membantu siswa dalam mencari dan menentukan suatu nilai yang dianggap baik dalam menghadapi suatu persoalan melalui proses menganalisis nilai yang sudah ada dan tertanam dalam diri siswa". Dari pendapat Sanjaya tersebut nampak bahwa VCT merupakan model yang sangat baik dan tepat dalam meningkatkan kompetensi moral judgement atau penalaran moral. Hal ini dikarenakan dalam VCT siswa dilatih untuk menemukan, memilih, menganalisis, memutuskan, mengambil sikap sendiri nilainilai hidup yang ingin diperjuangkannya seperti yang dikemukakan oleh Adisusilo (2012:141). Dengan beberapa tahap mulai dari menemukan, memilih, menganalisis, memutuskan, mengambil sikap sendiri serta bukan karena indoktrinasi atau penjelasan guru, siswa akan lebih mudah untuk memahami dan menginternalisasi nilai-nilai tersebut sehingga akan lebih terampil dalam menyelesaikan kasus dilematis moral.

Dengan meningkatnya kemampuan moral judgement ini diharapkan pula tingkah laku atau tindakan moral siswa juga menjadi lebih baik. Hal ini sejalan dengan pendapat Kohlberg (dalam Adisusilo, 2012:2) yang menyatakan "pertimbangan moral merupakan faktor yang amat menentukan perilaku moral". Pendapat ini juga memperkuat anggapan bahwa betapa pentingnya mengembangkan moral judgement pada anak usia sekolah dasar.

Selain membuktikan teori dan pendapat ahli di atas, penelitian ini juga sejalan dengan kajian penelitian yang dilakukan oleh Kd. Dewi Anggarini, I Nym. Murda, dan I Wyn. Sudiana dengan judul "Pengaruh Model Pembelajaran Value Clarification Technique Berbantuan Media Gambar terhadap Nilai Karakter Siswa Kelas V SD Gugus VI Tajun Kecamatan Kubutambahan Tahun Ajaran 2012/2013” yang dipublikasikan dalam jurnal online Universitas Pendidikan Ganesha Singaraja. Penelitian lain yang juga menunjukkan hasil senada dengan penelitian ini adalah penelitian yang dilakukan oleh Ni Pt. Yoni Rahayudhi, A. A. Gd. Agung, dan I Dw. Kade Tastra. Judul penelitian ini adalah "Pengaruh Model Pembelajaran VCT Berbantuan Media Microsoft Powerpoint terhadap Prestasi Belajar PKn Siswa Kelas V SD gugus II Kecamatan Tegallalang" yang dipublikasikan dalam jurnal online Universitas Pendidikan Ganesha Singaraja.

Dari uraian di atas, dapat dilihat bahwa penelitian ini sejalan dengan teori yang berkenaan dengan pembelajaran berbasis kognitif moral melalui model VCT serta beberapa kajian penelitian yang telah dikaji di depan. Meskipun demikian, terdapat beberapa catatan berkenaan dengan hasil penelitian. Sebagaimana telah diuraikan bahwa signifikansi dari penelitian ini adalah 0,042 dan hasil t hitung adalah 2,085. Dari hasil signifikansi 0,042 menunjukkan bahwa selisih angka tersebut sangatlah kecil dengan batas signifikansi yakni hanya 0,008 . Selain ditinjau dari hasil signifikansi, hasil serupa juga dapat dilihat dari hasil t hitung yang menunjukkan selisih yang juga sangat tipis, yakni hanya 0,08012. Beberapa aspek yang diduga berpengaruh terhadap kecilnya selisih antara hasil penelitian dengan standar atau batas minimum diantaranya adalah berkenaan dengan faktor-faktor yang mempengaruhi hasil belajar.

Beberapa faktor hasil belajar yang diduga berpengaruh tersebut adalah suasana pengajaran serta pribadi dan sikap guru (Ruseffendi dalam Ahmad Susanto 2013:1418). Aspek yang pertama adalah suasana pengajaran, pembelajaran $\mathrm{PKn}$ berbasis kognitif moral melalui model VCT di SD N Karangduren 01 dilaksanakan di ruang kelas 
2B bukan di ruang kelas yang biasanya digunakan oleh siswa kelas 5. Selain itu, suasana pembelajaran agak berbeda dengan hari-hari biasa karena saat itu sedang dilaksanakan try out untuk siswa kelas 6 dan siswa juga dilarang untuk bebas bermain. Suasana serupa juga terjadi SD Karangduren 02 yang bertindak sebagai kelas kontrol. Pembelajaran di kelas kontrol dilaksanakan di mushola sekolah. Pembelajaran di mushola sekolah dengan tempat duduk lesehan ini berdasarkan hasil pengamatan mempunyai dampak positif untuk proses diskusi kelompok. Pada saat diskusi dengan tempat duduk lesehan dan posisi melingkar membuat siswa lebih intens dalam berdiskusi sehingga memberi rasa nyaman dan suasana diskusi yang berbeda dari biasanya. Faktor kedua adalah pribadi dan sikap guru. Perlu diketahui, pengampu mata pelajaran PKn pada kelas eksperimen adalah Ibu Kepala Sekolah SD N Karangduren 01. Diduga faktor ini juga berpengaruh terhadap hasil belajar, karena sebagai seorang kepala sekolah memiliki tanggung jawab yang besar terhadap kelancaran serta hasil try out siswa kelas 6. Dugaan tentang faktor ini juga diperkuat karena pengajar PKn pada kelas kontrol adalah guru kelas 5 yang tentunya beban pikiran yang ada dalam dua pengajar di kelas eksperimen dan kelas kontrol juga berbeda.

\section{SIMPULAN}

Berdasarkan hasil penelitian dan pembahasan dapat disimpulkan bahwa penerapan pembelajaran berbasis kognitif moral melalui model VCT efektif terhadap hasil belajar PKn dengan mempertimbangkan moral judgement siswa kelas 5 SD N Karangduren 01 Kecamatan Tengaran Kabupaten Semarang semester II tahun pelajaran 2014/2015. Keefektifan tersebut dibuktikan dalam uji hipotesis yang didasarkan atas hasil uji t pada uji independent sample t test dengan hasil t hitung yang lebih besar dari t tabel $(2,085>2,00488)$ serta signifikasi yang lebih kecil dari 0,05 $(0,042<0,05)$.

Keefektifan tersebut juga dapat dilihat dari perbedaan rata-rata skor hasil belajar PKn kelas eksperimen dan kelas kontrol. Rata-rata skor hasil belajar PKn kelas eksperimen lebih tinggi daripada kelas kontrol sebagaimana dapat dilihat pada analisis deskriptif yang menunjukkan ratarata skor hasil belajar kelas eskperimen adalah 76,2 sedangkan kelas kontrol 68,5. Perbedaan rata-rata (mean different) tersebut dapat dilihat pada hasil uji t yakni independent samples $t$ test yang menunjukkan nilai perbedaan rata-rata (mean different) adalah 7,629 yang berkisar antara 0,292 sampai 14,965 .

\section{DAFTAR PUSTAKA}

Adisusilo, SutarjoJ. R. 2012. PembelajaranNilai Karakter. Jakarta: Raja Grafindo Persada.

Mawardi. 2011. Kajian Kurikulum PKn SD. Salatiga: Widya Sari Press.

Peraturan Menteri Pendidikan Nasional Republik Indonesia No. 22 Tahun 2006 tentang Standar Isi Kurikulum Tingkat Satuan Pendidikan. 2006. Jakarta: Kementrian Pendidikan Nasional.

Priyatno, Duwi. 2010. Teknik Mudah Dan Cepat Melakukan Analisis Data dengan SPSS. Yogyakarta: Gava Media.

Rahayudhi, Ni Pt.Yoni A.A. Gd.Agung, dan I Dw. Kade Tastra. 2012. "Pengaruh Model Pembelajaran VCT Berbantuan Media Microsoft Powerpoint Terhadap Prestasi Belajar Pkn Siswa Kelas V SD gugus II Kecamatan Tegallalang”. Pusat Publikasi Jurnal Universitas Pendidikan Ganesha Jurusan PGSD FIP. 1:2-10 
Ruminiati. 2007. Pengembangan Pendidikan Kewarganegaraan SD. Jakarta: Direktorat Jenderal Pendidikan Tinggi Depatermen Pendidikan Nasional.

Sanjaya, Wina. 2006. Strategi Pembelajaran. Jakarta: Perpustakaan Nasional. 2008. Strategi Pembelajaran Berorientasi Standar Proses Pendidikan. Jakarta: Kencana Prenada Media Group.

Sarbaini. 2012. Model Pembelajaran Berbasis Kognitif Moral. Yogyakarta: Aswaja Pressindo.

Sardiman. 2007. Interaksi \& Motivasi Belajar Mengajar. Jakarta: PT. Raja Jaya.

Sudiana, I Wayan, Kd. Dewi Anggarini, dan I Nyoman Murda. 2012 "Pengaruh Model Pembelajaran Value Clarification Technique Berbantuan Media Gambar Terhadap Nilai Karakter Siswa Kelas
V SD Gugus VI Tajun Kecamatan Kubutambahan Tahun Ajaran 2012/ 2013". Pusat Publikasi Jurnal Universitas Pendidikan Ganesha Jurusan PGSD FIP. 1:2-9

Sudjana. 2010. Metode \& Teknik Pembelajaran Partisipatif. Bandung: Falah Production.

Sugiyono. 2010a. Metode Penelitian Pendidikan Pendekatan Kualitatif, Kuntitatif, dan $R \& D$. Bandung: Alfabeta.

Susanto, Ahmad. 2013. Teori Belajar dan Pembelajaran di Sekolah Dasar. Jakarta: Kencana Prenada Media Group.

Taniredja, Tukiran, Efi Mitfah Faridli dan Sri Harmianto. 2011. Model-Model Pembelajaran Inovatif. Bandung: Alfabeta.

Zuchdi, Darmiati. 2008. Humanisasi Pendidikan. Jakarta: Bumi Aksara. 